\title{
"A necessidade carece de ley": valorização da mão de obra indígena e africana no Grão-Pará (1748-1778)
}

\author{
Antonio Otaviano Vieira Junior ${ }^{1 *}$ \\ ${ }^{1}$ Universidade Federal do Pará, Belém, Pará, Brasil
}

\section{RESUMO}

Dialogando com o contexto de alta mortalidade indígena gerada por uma epidemia, e o esforço da administração de D. José I em inserir regularmente cativos africanos no Grão-Pará, o artigo analisa tensóes entre dois projetos relacionados ao uso da máo de obra na capitania. De um lado, estava a intensificação da escravidão indígena e seu uso como principal força de trabalho na região. Do outro, a tentativa de incorporação regular do cativo africano na base da economia local. A análise se apoia no escrutínio de episódios pontuais: a publicação de uma Bula papal, a dissimulação do governador do Maranhão e a resistência à utilização do trabalho africano.

Palavras-chave: Grão-Pará; escravidão; índio; africano; morador.

\section{"A necessidade carece de ley": valorization of indigenous and African labor force in Gráo-Pará (1748-1778)}

\section{ABSTRACT}

This article proposes an analysis of the tensions that characterized the defense of two projects related to the use of labor in Grão-Pará, emphasizing a context of high indigenous mortality caused by an epidemic, the effort of the administration of D. José I to regularly insert African captives in Grão-Pará, and the creation of Companhia de Comércio do Grão-Pará and Maranhão. Besides the effort to intensify indigenous slavery and ensure its use as the main labor force in the region, there was also an attempt to make African captives the basis of the local economy. The analysis is based on the scrutiny of specific

DOI: http://dx.doi.org/10.1590/2237-101X02004208.

Artigo recebido em 14 de junho de 2018 e aceito para publicação em 4 de janeiro de 2019.

* Professor da Universidade Federal do Pará / Instituto de Filosofia e Ciências Humanas / Faculdade de História, Belém/PA - Brasil. E-mail: otaviano@pq.cnpq.br. ORCID: https://orcid.org/0000-0002-4785-1529. 
episodes: publication of a papal bull, the dissimulation of the governor's lie and resistance to the use of African labor.

Keywords: Grão-Pará; work; indigenous; African; resident.

\section{"La necesidad carece de ley": valorización de la mano de obra indígena y africana en Gráo-Pará (1748-1778)}

\section{RESUMEN}

Dialogando con el contexto de alta mortalidad indígena generada por una epidemia, y el esfuerzo de la administración de D. José I en inserir regularmente cautivos africanos en Grão-Pará, el artículo analiza las tensiones entre dos proyectos relacionados al uso de mano de obra en la capitanía. De un lado estaba la intensificación de la esclavitud indígena y su uso como principal fuerza de trabajo en la región. El análisis se apoya en el escrutinio de episodios puntuales: la publicación de una Bula Papal, el ocultamiento del gobernador de Maranhão y la resistencia a la utilización del trabajo africano.

Palabras clave: Grão-Pará; esclavitud; indio; africano; morador.

\section{Apresentação}

O Estado do Maranhão ${ }^{1}$ se apoiava, fundamentalmente, no trabalho indígena até meados do século XVIII. ${ }^{2}$ A região foi marcada por contínuas tensões em torno da regulação e monopólio desses trabalhadores, gerando uma série de conflitos entre índios, religiosos, moradores ${ }^{3}$, autoridades locais e a Coroa. ${ }^{4}$ Os eventos aqui apresentados estão relacionados ao esforço da monarquia portuguesa em assegurar a posse da América setentrional, à política

\footnotetext{
${ }^{1}$ Entre 1621 e 1751, era chamado Estado do Maranhão. A partir de 1751, passa a ser chamado de Estado do Grão-Pará e Maranhão, composto pelas capitanias do Rio Negro, Grão-Pará, Maranhão e Piauí.

${ }^{2}$ SOUZA JR., José Alves. Índios: mãos e pés dos senhores da Amazônia colonial. Fronteras de la Historia, Bogotá, vol. 16-2, p. 365-391, 2011.

${ }^{3}$ Moradores: habitantes de uma circunscrição administrativa e "formam um conjunto de pessoas de diferentes qualidades institucionais definidas" e que também possuem propriedades, cf: VAINFAS, Ronaldo. Dicionário do Brasil Colonial (1500-1808). Rio de Janeiro: Objetiva, 2000, p. 409. Embora, na maioria dos casos, o termo se referisse a brancos, ele não é necessariamente racial; embora fosse étnico, cf: ALMEIDA, Maria. A Falácia do Povoamento: ocupação portuguesa na Amazônia setecentista. In: COELHO, Mauro Cesar. Meandros da História. Belém: Unamaz, 2005. p. 21-33.

${ }^{4}$ SOUZA JR., José Alves. Jesuítas, colonos e índios: a disputa pelo controle e exploração do trabalho indígena. In: ALONSO, José Luis \& CHAMBOULEYRON, Rafael (org.). T(r)ópicos de História: gente, espaço e tempo na Amazônia (séculos XVII-XXI). Belém: Editora Açaí, 2010, p. 47-64.
} 


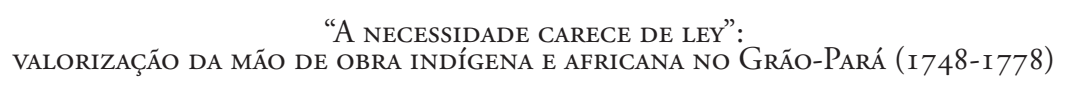

Antonio Otaviano Vieira Junior

voltada ao controle das aldeias por leigos, ao balizamento de açôes em que o indígena passa a ser considerado meio eficaz de povoamento, à agricultura como atividade econômica mercantil e à intensificaçáo de trocas comerciais sob o auspício da metrópole e da Companhia de Comércio monopolista. ${ }^{5}$ Nessa conjuntura, podemos observar a formação de dois projetos antagônicos: um valorizava o cativeiro indígena enquanto meio eficaz para o desenvolvimento e a sobrevivência da economia "amazônica", o outro apostava no escravo africano e na liberdade do índio como ferramentas para redinamizarem a economia local.

\section{A Coroa e o acesso à mão de obra indígena}

Por ocasião da criação da Lei de Liberdade Geral dos Índios de 1755, D. José I registrou um breve histórico do empenho e insucesso de seus antecessores na regulação da escravidão indígena. O monarca destacou que, nos anos de 1570, 1587, 1595, 1609, 1611, 1647, $1655 \mathrm{e}$ 1680, houve tentativas de imposição legislativa da Coroa na matéria, e tais leis enfrentaram resistências baseadas na "cubiça dos interesses particulares". ${ }^{6} \mathrm{O}$ destaque aponta para a relação entre a construção da legislação indigenista e uma miríade de tensốes.?

As leis foram publicadas de maneira sucessiva e, pela ineficácia da imposição de suas diretivas, logo eram substituídas. No ano de 1611, foi criada a Junta das Missōes que instituía a legitimidade da escravidão do índio ${ }^{8}$ e estabelecia como secular a administração dos aldeamentos. ' Entre 1647 e 1649, a legislação de D. João IV proibia o cativeiro indígena, só autorizava o uso do trabalho nativo mediante o pagamento de salários e da garantia que esses "assoldados" pudessem cultivar livremente seus roçados durante quatro meses ao ano caiu em letra morta. ${ }^{10}$ A provisão de 1655 assegurou a existência da Junta das Missóes como tribunal consultivo e restabeleceu o controle missionário nas aldeias. Apesar do aparente fortalecimento da ingerência jesuítica, a década de 1650 assistiu à intensificação das emprei-

\footnotetext{
5 BOXER, Charles. A Idade de Ouro do Brasil. São Paulo: Companhia Ed. Nacional,1963, p. 255-280. COSTA, João Paulo Oliveira (org.). História da expansão e do Império Português. Lisboa: Bertrand, 2014, p. 264-295.

${ }^{6}$ Biblioteca Nacional de Portugal (BNP). "LEY, PORQUE V. MAGESTADE HA POR BEM RESTITUIR AOS INDIOS DO GRÃO PARÁ, E MARANHÃO A LIBERDADE DAS SUAS PESSOAS, E BENS, E COMMERCIO, DADA EM 6 DE JUNHO DE 1755".

${ }^{7}$ COELHO, Mauro Cezar. Do sertão para o mar: um estudo sobre a experiência da América, a partir da Colônia; o caso do Diretório dos Índios (1750-1798). Tese de Doutorado, Universidade de São Paulo, 2005.

${ }^{8}$ GUZMÀN, Décio. Guerras na Amazônia do século XVIII: resistência indígena à colonização. Belém: Estudos Amazônicos, 2012, p. 47. As normas que legitimavam a escravização do nativo no Estado do Maranhão se baseavam no princípio português de "Guerra Justa". E era justo o cativeiro de índios capturados em guerras intertribais, os chamados "índios de corda", e que estariam fadados à morte como prisioneiros de guerra. O que tornava a legislação ambivalente, no sentido de não se aplicar a todos os índios, mas, somente aos inimigos da Coroa e da Igreja.

${ }^{9}$ SOUZA JR. Tramas do cotidiano..., op. cit. p. 186.

${ }^{10}$ SOUZA JR., José Alves. Jesuitas, colonos e indios..., op. cit., 48.
} 
tadas (legítimas ou não) para captura de escravos índios - inclusive com forte participação de autoridades locais do Estado do Maranhão. ${ }^{11}$

A não eficácia da regulação contribuiu para o rei Pedro II se manifestar a respeito da fragilidade metropolitana em assegurar a imposição de seus ditames. Em 1680, criou o decreto que proibia a escravidão indígena: "mando daqui em diante se não possa cativar Índio algum do dito Estado [Maranhão] em nenhum caso" ${ }^{12}$ E mesmo os índios aprisionados em guerras deveriam ser tratados enquanto prisioneiros "como as pessoas que se tomão nas guerras de Europa" ${ }^{13}$ Em 1682, criou a Companhia de Comércio do Maranhão com o objetivo de inserir escravos africanos na região e atenuar a pressão dos moradores por mão de obra. Mas, sem sucesso, a Companhia foi extinta em 1685.

A Lei de 1680 e a entrada de africanos tiveram o alcance limitado. E, em mais um esforço de regular o acesso ao trabalho indígena, a Coroa criou o Regimento das Missóes (16861757), ${ }^{14}$ na tentativa de diminuir o tráfico clandestino de trabalhadores índios e proibir a moradia de colonos nas aldeias. O Regimento assegurava o controle religioso dos aldeamentos e o dividia entre diferentes ordens religiosas. Em contrapartida, no ano de 1686, foi expedido um Alvará que permitia novos "resgates". ${ }^{15}$ Tais iniciativas geraram insatisfação dos moradores $^{16}$ e religiosos e o consequente não cumprimento das diretrizes do Regimento das Missóes.

A Coroa, ao longo dos anos, procurou se equilibrar entre as demandas dos colonos e dos religiosos. Com a cumplicidade de autoridades locais, os moradores submetiam ao cativeiro tanto os índios "inimigos" ${ }^{17}$ quanto os índios recebidos oficialmente, também não sendo raros os ataques contra os aldeamentos religiosos. Por sua vez, os missionários eram acusados de se favorecerem do controle dos aldeamentos para intensificarem a exploração das "drogas do sertão" e acumularem riquezas. Assim, no final do reinado de D. João V e início de D. José I, mais açóes sobre o tema foram tomadas. Sobre isso, passaremos a tratar ao longo do artigo.

\section{Bula papal e as reclamaçóes do bispo}

Iniciaremos com a análise da carta escrita em 13 de junho de 1757. Fora redigida pelo bispo do Grão-Pará, Frei Miguel de Bulhões e Sousa, e destinada ao secretário real, Sebastião

\footnotetext{
${ }^{11}$ SOUZA JR., José Alves. Tramas do cotidiano..., op. cit., p. 187.

${ }^{12}$ BNP. "LEY, PORQUE V. MAGESTADE HA POR BEM RESTITUIR AOS INDIOS DO GRÃO PARÁ, E MARANHÂO A LIBERDADE DAS SUAS PESSOAS, E BENS, E COMMERCIO, DADA EM 6 DE JUNHO DE 1755”.

${ }^{13}$ Idem.

${ }^{14}$ MELLO, Marcia Eliane. O Regimento das Missões: poder e negociaçóes na Amazônia Portuguesa. Revista Clio, Recife, n. 27, p. 46-75, 2009.

${ }^{15}$ Idem.

${ }^{16}$ SOUZA JR., Índios: mãos e pés... op. cit.

${ }^{17}$ Índio "inimigo" era aquele que poderia ser alvo das Tropas de Resgate, pois se opunham em armas ou por fugas ao projeto colonizador lusitano.
} 
José de Carvalho e Melo. O tema central da correspondência era o imbróglio que envolveu a publicação de uma Bula papal na cidade de Belém.

Miguel de Bulhóes foi professor de filosofia e teologia e integrou a Academia Real de História. Em 1745, alcançou a nomeação como bispo de Malaca. Não chegou a exercer o cargo por ser transferido para a diocese de Belém. ${ }^{18}$ No mês de fevereiro de 1749 , então com 43 anos de idade, desembarcou no porto da cidade trazendo na bagagem uma Bula do papa Bento XIV, que lhe foi entregue em 1748 pelo secretário particular de D. João V, Fr. Gaspar da Encarnação. ${ }^{19}$ Tratava de um ponto extremamente delicado para os habitantes do Estado do Maranhão: "para desterras de todo o injusto captiveiro dos mesmos Índios a mandasse [a Bula] publicar apenas chegasse a esta diocese". ${ }^{20}$ A Bula foi assinada em 20 de dezembro de $1741,{ }^{21}$ chegou à cidade de Belém em 1749 e não foi imediatamente publicada .

Antes de publicá-la, Miguel de Bulhões marcou uma reunião com as "pessoas principais desta Cidade [Belém]". Era a tentativa de não "causar nesta Capitania alguma sublevação, nem expor ao iminente perigo de ser ultrajada esta Ley do Papa.... ${ }^{22}$ No plenário, o bispo apelou para o "lastimoso estado, a que se achavão reduzidas as suas consciências por causa da notória injustiça, com que captivão os Índios sem guardar a forma prescrita pelas Reaes ordens de S Mage (grifo nosso)". Procurou ressaltar que a Bula contava com o apoio das duas principais autoridades do mundo católico lusitano, Bento XIV e D. João V: “o Vigario de Christo (...) conferindo esta importantíssima matéria com o nosso Augusto Soberano, tinha prohibido com pena de Excomunhão reservada e mais censuras Eclesiásticas os referidos captiveiros". ${ }^{23}$

Miguel de Bulhões argumentou que a Bula não propunha acabar com a escravidão indígena e sim garantir a regulação do cativeiro. Apesar da ponderação, a Bula não fora bem recebida "pelas pessoas principaes": "Não posso explicar a V. Mage os imprudentes clamores e iníquos requerimentos com q a barbaridade destes homens, creados com o mortífero veneno de tantas injustiças pertendeo embaraçar a publicação da dita Bulla”. ${ }^{24} \mathrm{~A}$ importância do trabalho indígena para a manutenção das propriedades dos colonos balizava esse embate contra as determinaçôes do ultramar. ${ }^{25}$ Miguel de Bulhôes logo entendeu que os moradores reconheciam o "deplorável estado das suas consciências". Os colonos assumiam "irreme-

\footnotetext{
${ }^{18}$ FONSECA, João Abel. D. Frei Miguel de Bulhōes, Bispo do Pará e Governador do Estado do Grão-Pará e Maranhão. 1752-1756. In: Congresso Internacional de História Missionaçâo Portuguesa e Encontro de Culturas, 1993, Braga. Actas... Braga: Fundação Evangelização e Culturas, vol. II, 1993, p. 492.

${ }^{19}$ SILVA, Maria Beatriz Nizza da. D. João V. Lisboa: Círculo dos Leitores, 2006, p. 204.

${ }^{20}$ Arquivo Nacional de Portugal/ Torre do Tombo (ANTT), Fundo Ministério do Reino, Mç. 598, doc. 55.

${ }^{21}$ Bularium Benedicti XIV. Tomus Primi. Roma: Typographi Celsiss, vol. I, 1826, p. 204.

${ }^{22}$ ANTT, Fundo Ministério do Reino, Mç. 598, doc. 55.

${ }^{23}$ Idem.

${ }^{24}$ Idem.

${ }^{25}$ Cf: FRAGOSO, João et al. O Antigo Regime nos trópicos. Rio de Janeiro: Civilização Brasileira, 2001.
} 


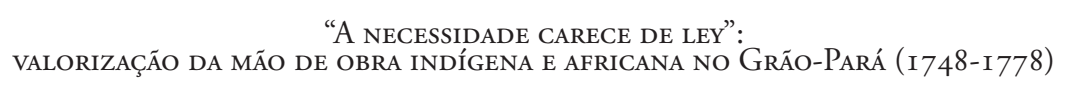

Antonio Otaviano Vieira Junior

diável seu mal, porque sem embargo de quantas Bullas emanassem do Vaticano, eles sempre havião de continuar na violência dos mesmos Captiveiros". ${ }^{26}$

Contundentemente, os moradores intimidaram o bispo: "chegarão a romper em ameaças, trazendo-me a Lembrança o que tinha succedido ao $\mathrm{S}^{\mathrm{r}} \mathrm{D}$. Fr. Thimoteo do Sacramento, bispo do Maranhão". ${ }^{27} \mathrm{O}$ episódio ocorrido em 1700 era uma lembrança temerária para autoridades eclesiásticas da regiáo. E o era por ser um evento onde o Fr. Thimoteo do Sacramento teve o palácio episcopal cercado por tropas militares e foi obrigado a retornar para Lisboa. ${ }^{28}$ Quase 50 anos depois, a memória do embate seria utilizada contra a Bula papal.

Numa tentativa de intimidação, o bispo Miguel de Bulhôes solicitou aos moradores a redação de uma espécie de carta justificativa. Nela deveriam registrar, por escrito e publicamente, as motivaçôes que os levavam a desobedecer às determinaçóes papais: "chegando esta [carta justificativa] em minhas mãos, e vendo que era tal a rusticidade e a obstinação destes homens, que chegarão a confessar em hum papel publico a sua impertinência...." ${ }^{29} \mathrm{O}$ pedido não intimidara os moradores e nem abrandara a resistência daqueles que se recusavam a aceitar a ingerência papal e as determinaçóes reais. $\mathrm{O}$ documento foi escrito no dia $25 \mathrm{de}$ maio de 1750. A "impertinência” fora referendada por 136 assinaturas, inclusive de juízes, procurador do Conselho, escriváo da Câmara e vereadores.

Os anos de 1748-1750 coincidiram com uma epidemia e alta mortalidade de índios ${ }^{30}$ : "Estamos hoje, como V. Ex $x^{\mathrm{a}}$ muito bem conhece, na mayor necessidade de escravos pelas epidemias passadas (grifo nosso), que deles nos privarão e esta mesma penúria pois a necessidade carece de Ley, nos há de obrigar a procurallos de mil modos". ${ }^{31}$ A carta justificativa explorava o contexto no qual a publicação da Bula se inseria, apresentando-o como pouco favorável aos moradores. Os signatários entendiam que a Bula visava combater o "injusto captiveiro dos mesmo Índios”. O que por si só era uma ameaça, principalmente num quadro de diminuição na oferta de trabalhadores. Afirmavam que tal regulação poderia ser confundida com o fim da escravidão indígena:

nenhum efeyto pode fazer a Bulla mais que de causar alguma alteração nos Índios que já se achão escravos e entenderem como já entendem que todos são forros, e quem os possue excomungados, e que Livremente se podem auzentar, entendendo, que a Excomunhão também prohibe a prucurallos. ${ }^{32}$

\footnotetext{
${ }^{26}$ ANTT, Fundo Ministério do Reino, Mç. 598, doc. 55.

${ }^{27}$ ANTT, Fundo Ministério do Reino, Mç. 598, doc. 55.

${ }^{28}$ PAIVA, José Pedro. Os bispos do Brasil e a formação da sociedade colonial (1551-1706). Textos de História -Pós-Graduação em História da UNB. Brasília-DF, v. 14, n.1/2, p. 19, 2006, p. 29.

${ }^{29}$ ANTT, Fundo Ministério do Reino, Mç. 598, doc. 55.

${ }^{30}$ VIEIRA JR., Antonio Otaviano e MARTINS, Roberta. Epidemia de sarampo e trabalho escravo no Grão-Pará (1748-1778). Revista Brasileira de Estudos de População, Campinas, 2015, v. 32, n. 2, p. 293-311.

${ }^{31}$ ANTT, Fundo Ministério do Reino, Mç. 598, doc. 55.

${ }^{32}$ Idem.
} 
"A NECESSIDADE CARECE DE LEY":

VALORIZAÇÃo DA MÃo DE OBRA INDÍGENA E AFRICANA NO GRÃO-PARÁ (I 748-I778)

Antonio Otaviano Vieira Junior

Na carta justificativa, assinada e enviada à mais alta autoridade eclesiástica da capitania, parte dos moradores do Grão-Pará se posicionava explicitamente contra as determinaçóes do Vaticano e de Lisboa:

não assentimos na dita Bulla, pois obrando Nós como somos obrigados por Catholicos não carecemos dela, e se algum por miséria se athrever a esquecer-se da sua Consciencia, também fica a mesma Bulla frustatoria, porque aquillo que por temor de Deos se não obra, não se consegue pelo Castigo (...) [e se as ameaças de castigos fossem suficientes] não haveriāo sombras de tal Culpas à vista das apertadas Leys de S. Mage. sobre este particular, pelas quaes se devaça todos os annos, e se punem os culpados rigorosamente... ${ }^{33}$

Os 136 signatários invocavam e reconheciam o "afim Santo" da Bula por significar "muitas conveniências espirituais a todo este Povo". ${ }^{34}$ Mas argumentavam acerca do grande estado de miséria dos moradores. Eram expostas duas opçôes: de um lado, a consciência religiosa e, do outro, a sobrevivência física e econômica. Destacavam explicitamente a escravidão indígena como elemento fundamental para a existência dos colonos, "por não fazer mais agravante a chaga que se pertende sarar, escolhendo de dois males o menor, que he conservar o achaque, se na Cura dele pode perigar a vida". ${ }^{35}$

Tais argumentos surtiram efeito e adiaram a publicação da Bula até 1757. Nas palavras do bispo:

Chegando finalmente o tempo, porque eu tanto suspirava, de se publicar a Ley da Liberdade dos Índios, parecendo-me, que esta era a ocasiáo mais opportuna para que também se publicasse a referida Bulla, em ordem a evitar as doutrinas errôneas com que os Regulares poderiáo introduzir nestes ignorantisimos Povos a desobediência da dita Real Ley (...) Assim o executei a 29 de Mayo, dia do Espirito Santo, tendo-se publicado a outra Ley no dia antecedente. $^{36}$

Não foi só a Bula que se deparou com objeçôes, a Lei de Liberdade Geral do Índio também enfrentou resistência. O próprio governador Francisco Xavier de Mendonça Furtado precisou invocar a determinaçáo real que lhe atribuía o direito de escolher o melhor momento para publicação dessa Lei, se fazendo necessário convencer os moradores "para que os mesmos Povos estejam capacitados no novo Systema que se segue [uso de cativos africanos], (...) para no dito tempo chegarem mais alguns navios de Pretos para se irem fornecendo os

\footnotetext{
${ }^{33}$ ANTT, Fundo Ministério do Reino, Mç. 598, doc. 55.

${ }^{34}$ Idem.

${ }^{35}$ Idem.

${ }^{36}$ Idem.
} 


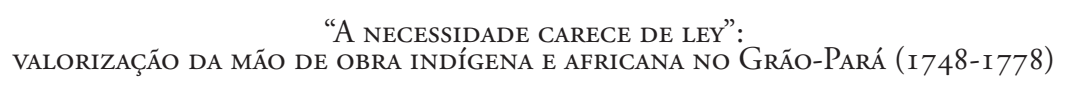

Antonio Otaviano Vieira Junior

Engenhos e Fazendas..." ${ }^{37} \mathrm{O}$ governador postergou por quase dois anos a publicação da Lei, porque esta reivindicava uma estratégia cuidadosa para combater a possibilidade de "Rebelião destes mizerabilissimos e ignorantíssimos homens" ${ }^{38}$ Mendonça Furtado destacava a importância da Bula para amenizar a possível resistência:

que também se deve considerar, se seria conveniente ordenasse ao Prelado Diocezano, que depois de publicada a Ley das Liberdades, publicasse igualmente hum Breve (sic), que tem do Papa Reynante o qual defende as escravidoens dos Indios ocidentaes com pena de excomunhão, e ajudando se as duas Espadas, fica inteiramente o negocio seguro...." ${ }^{39}$

No dia 28 de maio de 1757, sob o rufar de caixas pelas ruas da cidade de Belém, o governador anunciava a Lei de Liberdade Geral do Índio..$^{40}$ Enfim a Bula poderia ser publicada, mesmo que dezesseis anos após a assinatura do papa e oito anos depois do desembarque do bispo Miguel de Bulhōes no Grão-Pará.

\section{Um governador pouco sincero para com seu rei}

Francisco Pedro de Mendonça Gurjāo foi antecessor de Mendonça Furtado. Antes havia sido capitão-mor da Paraíba (1729-1734), governador da Ilha da Madeira (1737-1747) e do Estado do Maranhão (1747-1751) ${ }^{41}$, um homem atrelado ao esforço de governabilidade do Império. ${ }^{42}$ Em maio de 1749 , os vereadores de Belém ${ }^{43}$ enviaram uma carta destinada ao rei D. João V. Na missiva, foi ressaltado o estado precário das propriedades dos moradores, resultado da epidemia que havia diminuído significativamente o número de escravos. ${ }^{44}$

\footnotetext{
${ }^{37}$ Arquivo Ultramarino - Projeto Resgate (AU/PR), Capitania do Pará, 12 de novembro de 1755, cx. 39, doc. 3676.

${ }^{38}$ AU/PR, Capitania do Pará, 12 de novembro de 1755, cx. 39, doc. 3676.

${ }^{39}$ Idem.

${ }^{40}$ GOMES, Robeilton. Nos limites do poder: o processo de construção da lei de liberdade dos índios do Grão-Pará (1751 - 1757). Canoa do Tempo, Manaus, v. 9 - n. 1, dez 2017, p. 23.

${ }^{41}$ Fabiano Vilaça dos SANTOS. Da Paraíba ao Estado do Maranhão: trajetórias de governo na América Portuguesa (séculos XVII e XVIII), Revista de História, São Paulo, n. 161, $2^{\circ}$ semestre de 2009, p. 59-83.

${ }^{42}$ FRAGOSO, João et al. Uma leitura do Brasil Colonial: bases da materialidade e da governabilidade do Império. Revista Penélope, Oeiras, nº 23, 2000, p. 67-88.

43 A câmara significava um importante mecanismo de organizaçáo institucional e defesa de grupos privilegiados, sendo ferramenta de oposição ao poder central do Império. HESPANHA, Antonio Manuel. A constituição do Império Português: revisão de alguns enviesamentos correntes. In: FRAGOSO, João et. al. O Antigo Regime nos trópicos. Rio de Janeiro: Civilização Brasileira, 2001, p. 164-188. FEIO, David Salomão. $O$ nó da rede de 'apaniguados': oficiais das câmaras e poder político no Estado do Maranhão (primeira metade do século XVIII). Dissertação (Mestrado em História Social), Programa em História Social da Amazônia, Universidade Federal do Pará, Belém, 2013.
}

${ }^{44}$ AU/PR, Capitania do Pará, 30 de maio de 1749, cx. 31, doc. 2917. 


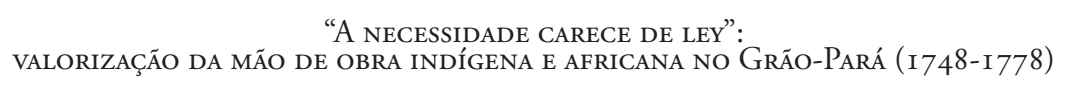

Antonio Otaviano Vieira Junior

Concomitantemente, denunciaram Francisco Gurjão como empecilho para a solução do problema. E o era por:

que temos Requerido repetidas vezes ao Governador General do Estado desse providencia a esta tam grande necessidade se esquivou de deferir a ellas com pretexto de V. Mag impedir as ditas Tropas [de Resgate]. Rogamos e pedimos umildemente a V. Mage se compadeça destes seos necessitados vassalos e conçedendo lhes as Referidas Tropas de Resgate... ${ }^{45}$

No trecho citado, destacamos o termo "repetidas vezes" como indício da pressão exercida pela câmara sobre o governador e das sucessivas negaçóes feitas por este. Segundo o documento, o indeferimento da autorização se apoiava na suposta proibição das Tropas de Resgate. ${ }^{46} \mathrm{O}$ que foi apresentado como "pretexto" poderia ser, entretanto, a intenção de fazer valer a determinação real de 13 de junho de $1748 .^{47}$

$\mathrm{Na}$ mesma carta, os vereadores não apenas sugeriam a intensificação da captura de escravos indígenas. Traziam o pleito de complemento de mão de obra através da entrada de escravos africanos: "rogamos a V. Mage se digne mandar alguns navios de Pretos escravos". ${ }^{48}$ Aparentemente, o governador discordava dos vereadores. Não foi sem razão que havia negado várias solicitaçóes para a formação de Tropas de Resgate. Num primeiro olhar, somos levados a acreditar que Francisco Gurjão se uniria aos esforços do bispo Miguel de Bulhóes na imposição dos ditames vindos de Lisboa. Contudo, logo no seu primeiro ano no governo do Estado do Maranhão (1747), Francisco Gurjão havia demonstrado valorizar o cativeiro dos nativos. Na ocasiāo, se manifestou contrariado à determinação real de mandar retornar à cidade de Belém a Tropa de Resgate que andava pelo Rio Negro e Japurá. Afirmara que "se não pode recuperar a decadência em q ficarão estes moradores sem haver Tropa [de Resgate] donde Rezulte a abundancia de gente q he necessária para cultivarem suas lavouras...” 49

Em 1749, Francisco Gurjão defendeu outra proposta. Ao reivindicar o amparo de D. João V para enfrentar os danos causados pela epidemia no Grão-Pará, deixou de mencionar os braços nativos, passando a sugerir o financiamento da entrada de carregamentos de escravos africanos da Costa da Mina, de Guiné e de Cacheu. Segundo Gurjão, os “pretos” seriam mais resistentes às doenças do que os índios: "V. Mage por sua Real grandeza for servido

${ }^{45}$ AU/PR, Capitania do Pará, 30 de maio de 1749, cx. 31, doc. 2917.

46 Tropas de Resgates eram expedições militares que visavam negociar "índios de corda" ou simplesmente apreender índios dispersos na floresta.

${ }^{47}$ BNP, Coleção Pombalina, f. 348.

${ }^{48}$ AU/PR, Capitania do Pará, 30 de maio de 1749, cx. 31, doc. 2917. A demanda aparece desde o século XVII. Cf: CHAMBOULEYRON, Rafael. Suspiros por um escravo de Angola: discurso sobre a mão de obra africana na Amazônia seiscentista. Revista Humanitas, Belém, v. 20, n. 1/2, 2004, p. 99-111.

${ }^{49}$ AU/PR, Capitania Pará, 28 de outubro de 1747, cx. 29, doc. 2803. 
mandar [africanos] (...) q os Pretos resistem melhor q os Índios ao mal, em tal forma, q Raros Pretos forão acometidos dele [da epidemia], e não consta q perigasse algum." 50

A aparente dubiedade nos argumentos e pedidos do governador foi esclarecida na carta que enviou ao "amigo" e secretário particular de D. João V, Fr. Gaspar da Encarnação, o mesmo que entregara a Bula ao bispo. Nela, o governador, textualmente, assumia que havia ludibriado o rei com receio da intermediação do Conselho Ultramarino:

Nesta ocasião dou conta a S. Mag e pelo expediente do Conselho Ultramarino expondo lhe a total Ruyna deste Estado (...) na dita conta não fallo em Tropa [de Resgate], por q sey que no Conselho falarse hoje nesta matéria he, além de infrutífera deligencia, arriscar muito o credito, pois entendem que so serve para utilidade dos q governão, e por esta cauza só aponta o meyo dos prettos da Costa da Mina; porem como a V. $\mathrm{R}^{\text {ma. }}$ devo falar sem receyo de diminuir no conceito q de mim forma lhe seguro, q ainda q Sua Majestade queyra contribuir com hua grave despeza para mandar introduzir os prettos, nunca estes podem ser bastantes a suprir a falta, $\mathrm{q}$ se experimenta, e só algumas tropas de Resgattes q prontamente se expressão, he q poderão em parte Remediar a indigência destes moradores... ${ }^{51}$

Ao utilizar o secretário real como destinatário e confessar explicitamente sua dissimulação, o governador talvez tentasse contornar diretrizes associadas ao Conselho ${ }^{52}$ e conquistar o apoio de D. João V. O fato não seria novidade na administração joanina, pois o monarca, com bastante frequência, negligenciava as orientaçôes do citado Conselho e buscava a opinião de terceiros ${ }^{53}$ - destacamos a influência exercida por Gaspar da Encarnação como secretário do rei. ${ }^{54}$ Francisco Gurjão tentava atenuar sua crítica ao rei e depositá-la enfaticamente no Conselho Ultramarino, acusando-o de valorizar a escravidão africana e não reconhecer as especificidades locais. Mas seria adequada tal acusação?

Em maio de 1750, portanto próximo aos dias finais do reinado de D. João V, o Conselho produziu um documento com o objetivo de diagnosticar a situação do norte da América lusitana. O documento era uma resposta à contundente queixa do procurador da fazenda do Maranhão. Nele, o procurador e os conselheiros se manifestaram acerca da importância da escravidão/liberdade indígena.

\footnotetext{
${ }^{50}$ AU/PR, Capitania Pará, 26 de abril de 1749, cx. 31, doc. 2910.

${ }^{51}$ ANTT, Fundo Ministério do Reino, Mç. 597, doc. 02.

${ }^{52}$ BICALHO, Maria Fernanda \& COSTA, André. O Conselho Ultramarino e a emergência do Secretário de Estado na comunicação política entre Reino e Conquistas. In: FRAGOSO, João e MONTEIRO, Nuno (orgs.). Um reino e suas repúblicas no Atlântico. Rio de Janeiro: Civilizaçâo Brasileira, p. 137-158. A Coroa era constituída por uma série de conselhos, órgãos, tribunais, juntas e secretarias que em parte tinham jurisdição derivada do rei e em parte na sua própria auto-organização, p. 137.

${ }^{53}$ SILVA, Maria Beatriz Nizza da. D. João V, op. cit., p. 173.

${ }^{54}$ Cf: MONTEIRO, Nuno. D. José. Lisboa: Círculo dos Leitores, 2006, p. 51-56.
} 
O primeiro a se posicionar foi o próprio procurador que denunciou a falta de escravo pela "diminuição dos que falecerão na próxima epidemia, em que se fundarão os moradores do Pará para requererem a V. Mage. lhes tornasse a permitir tropas de Resgate". 55 Enfaticamente, deixou claro que, diante da carência de trabalhadores, "se devia practicar em ultimo lugar (grifo nosso) a introdução dos escravos negros de Guiné" ${ }^{66}$ A introdução de africanos não coibiria a "injusta” violência utilizada pelos moradores contra os índios. Outro motivo era a despesa da fazenda real na compra e no transporte dos africanos. Seria necessário fazer um levantamento detalhado sobre o número de escravos necessários, sua aplicação e como seriam introduzidos anualmente. A preocupação era de "que os que se destinarem a essa Conquista não fação falta nas outras, onde não há meyo de a remedear”. Em resumo, o parecer do procurador apontava o índio como trabalhador mais viável para a região e representava o Estado do Maranhão menos dependente dos "negros da Guiné” do que outras áreas do Império. ${ }^{57}$

$\mathrm{Na}$ continuação do documento, vieram os pareceres dos conselheiros. Inicialmente, se posicionou Fernando José Marques Bacalhau, que, citando a experiência do Estado do Brasil afirmava que este "comessou a florecer depois que se mandou cessar o cativeiro dos naturaes, e se introduzio dos negros". Sua argumentação não só se posicionava a favor do envio de africanos, mas era terminantemente contra a escravização dos índios: "Não hé mais poderoso o Rey, que domina dilatados paizes, mas sim o que tem mayor numero de vassalos, e estes são os que podem fazer mais crescidas as suas Rendas..." 58 Os "naturais" apareciam como alternativa ao processo de colonização e isso justificaria o fim da sua escravidão. ${ }^{59}$ Ainda sugeria a criação de uma Companhia de Comércio "em que entrem todos os negociantes que traficão para aquela Provincia, e todos os homens ricos dela...". ${ }^{60}$ Talvez estivesse tentando reeditar a Companhia de Comércio do Maranhão, criada em 1682. ${ }^{61}$

Outros dois conselheiros, Rafael Pires Pardinho e Alexandre Gusmão, afirmavam que "para se remediar a estante falta de escravos, que no Pará tem cauzado a prezente Epidemia, lhes parece será muito da piedade; e grandeza de V. Mage mandar por conta da sua real

\footnotetext{
${ }_{55}$ AU/PR, Capitania do Maranhão, 15 de maio de 1750, cx.31, doc. 3213.

${ }^{56} \mathrm{Idem}$.

${ }^{57}$ Idem.

${ }^{58} \mathrm{Idem}$.

${ }^{59}$ DOMINGUES, Ângela. 2000. Quando os indios eram vassalos: colonização e relaçôes de poder no Norte do Brasil, na segunda metade do século XVIII. Lisboa: Comissão Nacional de Comemoraçóes dos Descobrimentos Portugueses, 2000, p. 41-51. A autora destaca que como trabalhador a liberdade do índio se resumia ao direito de receber salário, no entanto eram tratados como trabalhadores que se encontrariam numa "menoridade civilizacional" e, por isso, carentes de uma tutela, não mais religiosa, mas, sim do Estado através dos administradores das vilas.

${ }^{60}$ AU/PR, Capitania do Maranháo, 15 de maio de 1750, cx.31, doc. 3213.

${ }^{61}$ DIEGUES JR., Miguel. As Companhias Privilegiadas no comércio colonial. Disponível em: http://www. revistas.usp.br/revhistoria/article/viewFile/34853/37591, p. 321. Acesso em: 6 fev. 2018.
} 
fazenda introduzir lhes algumas carregaçóes de pretos...". ${ }^{62}$ Os dois conselheiros eram a favor da entrada de africanos e se posicionavam contra a escravidão dos índios, propondo a renovação da Lei de Liberdade dos Índios de $1680 .{ }^{63} \mathrm{O}$ presidente do Conselho Ultramarino, o Marquês de Penalva, também se mostrou apoiando a introdução de africanos: "O primeiro arbítrio que se lhe oferece para suprir a falta dos Índios com a justa liberdade que se lhes deve dar he a introdução dos negros como nos outros domínios que tem V. Mage. tem na América". ${ }^{64}$ Dos seis conselheiros, Tomé Joaquim da Costa Corte Real e Alexandre de Souza e Menezes apoiavam a intensificação da escravidão indígena, mas ponderavam sobre a necessidade de uma maior regulação dos processos de aquisição dessa escravaria. ${ }^{65}$

Em resumo, parece-nos proceder a queixa feita pelo governador Francisco Gurjão ao "amigo" Gaspar da Encarnação. Havia uma tendência do Conselho Ultramarino em combater o cativeiro indígena e fomentar a escravidão africana. No esforço de analisar a situação do Estado do Maranhão, a maioria dos conselheiros creditava a crise "temporal e espiritual" aos abusos que os índios sofriam por conta de sua escravização. Para esses conselheiros, uma das alternativas era o binômio: liberdade geral dos índios e a entrada de escravos africanos. Francisco Gurjão talvez tivesse um álibi para mentir ao rei.

Em 16 de maio de 1750, o Conselho Ultramarino encaminhou o parecer final a D. João V:

Ao Conselho parece que o meyo, que se pode tomar para fornecer as Cappitanias do Pará e Maranham de cultores que suprão a falta de Indios de que o governador [Francisco Gurjão] dâ conta, he o de se facilitar naquelas Cappitanias a introducção dos pretos da Africa, como já se praticou em outra occasião, porem não pode ser conveniente fazer esta introducção por conta da Real fazenda como aponta o Governador... ${ }^{66}$

No episódio descrito, parece-nos que parte das diretrizes metropolitanas encontrava na principal autoridade leiga do Estado do Maranhão uma velada resistência. O governador, na prática, entrava em sintonia com parcela dos moradores da capitania do Grão-Pará. E o fazia por não conceber o desenvolvimento econômico e a sobrevivência dos colonos apartada da escravidão indígena. No reinado de D. José I, Francisco Gurjão iria ser substituído por alguém muito mais próximo da política de Lisboa: Francisco Xavier de Mendonça Furtado, meio-irmão do futuro Marquês de Pombal. Um gesto que significou a intensificação da ofensiva contra a escravidão indígena.

\footnotetext{
${ }^{62}$ AU/PR, Capitania do Maranhão, 15 de maio de 1750, cx. 31, doc. 3213.

${ }^{63}$ Idem.

${ }^{64} \mathrm{Idem}$.

${ }^{65}$ Idem.

${ }^{66}$ AU/PR, Capitania do Pará, 16 de maio de 1750, cx. 31, doc. 2976.
} 
"A NECESSIDADE CARECE DE LEY":

VALORIZAÇÃo DA MÃo DE OBRA INDÍGENA E AFRICANA NO GRÃO-PARÁ (I 748-I778)

Antonio Otaviano Vieira Junior

\section{Resistência à solução africana}

O fim da epidemia de 1750, a nomeação e posse de Mendonça Furtado como governador do Estado do Maranhão, a publicação da Lei de Liberdade Geral do Índio, o Diretório e a criação da Companhia Geral de Comércio do Grão-Pará e Maranhão marcaram um período de confrontos acerca da inserção e utilização do trabalho escravo africano na Amazônia. Passaremos a analisar documentos que partiram de Belém para Lisboa e tinham a intenção de desqualificar a utilização desses trabalhadores.

Iniciamos com uma carta anônima produzida logo após Mendonça Furtado fazer sua primeira audiência no senado de Belém (1751-1752). O objetivo do documento, ao qual também chamaremos de manifesto, era "dar com mais acerto Resposta a Proposta, q o Sr. General da parte de sua Magestade, que Deos guarde propôs ao Senado da Camara sobre a Introduçáo de pretos neste Estado (grifo nosso)" ${ }^{67} \mathrm{O}$ autor (o documento foi escrito na primeira pessoa do singular) deixava claro que o governador era um intermediário das reais decisões e essas mereciam mais acurada análise. Para tanto, se fazia necessário "averiguar hua matéria de tanta ponderação, de que com muita razão se queixa o pouco, e ainda os mesmos, q assignarão...." ${ }^{68}$

O manifesto avançava de maneira intensa e, de imediato, adjetivava a decisão do rei: "me parece se devia primeiro discotir a cauza de hua tam inopinada (grifo nosso) resolução de sua Real Majestade". ${ }^{69}$ A resolução se ancoraria na ideia de "que os Tapuyas não podem ou não devem ser escravos o que hé notoriamente falso". ${ }^{70}$ Segundo o documento, a medida carecia de esclarecimento acerca das consequências para "a boa conservação do seu Estado, e estabelecimento dos seus Vassallos" ${ }^{71} \mathrm{Na}$ carta, o rei foi tratado como alguém distante da realidade da regiáo e carente de informação acerca das consequências de sua determinação: "Reprezentado lhe porem os inconvenientes presentes, o que de futuro podem acontecer ...." 72

A introdução do manifesto vai explicitamente de encontro às reais decisões. A Coroa era tratada como desinformada e ameaçada pelo autor do escrito, que se assumia como a voz dos "vassalos". O objetivo do texto era informar melhor ao rei e fazê-lo reverter sua decisão. Caso não convencessem, os "vassalos" estariam prontos para resistir:

Reprezentado the porem os inconvenientes presentes, e que de futuro podem acontecer ponderados já nas leys ao diante apontadas, para a vista delas tomar o mesmo Senhor a ultima

\footnotetext{
${ }^{67}$ ANTT, Fundo Ministério do Reino, Mç. 597, doc. 03.

${ }^{68}$ Idem.

${ }^{69}$ Idem.

${ }^{70}$ Idem.

${ }^{71}$ Idem.

${ }^{72}$ Idem.
} 
"A NECESSIDADE CARECE DE LEY":

VALORIZAÇÃo DA MÃo DE OBRA INDÍGENA E AFRICANA NO GRÃO-PARÁ (I 748-I778)

Antonio Otaviano Vieira Junior

Rezoluçam, a qual protestamos abraçar, e executar lhe onde chegarem as nossas forças e possibilidades. ${ }^{73}$

O rei deveria ser persuadido e, para tanto, o documento seguia construindo argumentos baseados fundamentalmente em dois eixos: a legitimação da escravidão do índio e a não qualificação do trabalho africano.

$\mathrm{O}$ esforço de ponderar acerca da legitimação do cativeiro indígena se baseava em reflexóes filosóficas e na história administrativa do Estado do Maranhão. Os argumentos citavam autores como o frei e filosofo católico Sabino Bononiense, afirmando que, embora nenhum homem possa ser escravo de outro por direito da natureza, alguns nascem mais "hábeis" a servir e outros a imperar - a escravidão como punição ao pecado. E por direito das "gentes e civil, pode hum homem ser escravo de outro, o que prova com vários lugares da sagrada escripturas..." ${ }^{74}$ Ainda apoiado nas ideias de Bononiense, conclui: "Assim como cautherizar ou cortar hum braço, ou perna a hum homem, he contra a natureza segundo sua primeira Constituição; não he porem contra a Razão suposta a infermidade. Esta doutrina he indubtavel" ${ }^{75}$ Resumidamente, a escravidão era apresentada como uma constante na Bíblia e, apesar de ser um mal, era um mal necessário. Tacitamente, tramava um argumento onde a amputação de um membro (a liberdade indígena) significava a salvação do resto do corpo (o Estado do Grão-Pará).

O manifesto invocava a presença do pensador católico e autor da obra $A$ luz moral, ${ }^{76}$ traduzida para o português em 1737. O escrito influenciou um ciclo de concepção da moral católica na América portuguesa, cuja lógica valorizava a salvação da alma como principal objetivo da vida na terra. ${ }^{77} \mathrm{O}$ uso das reflexóes de Bononiense teria como possível desdobramento a ideia de que o eventual sofrimento do índio cativo poderia se justificar através da salvação de sua alma e da vida eterna.

$\mathrm{O}$ manifesto também citou os Salmatienses. Esses eram autores espanhóis utilizados na formação dos Carmelitas Descalços em Alcalá e Salamanca, que versavam acerca da legitimação da escravidão: dentro da legislação civil, um crime pode ser considerado passivo de punição com o cativeiro. É o que os "Reis dos pretos, e os Principes ou Principais dos Tapuyas, em virtudes das leys, e costumes com q se governão, castigar com pena de escravidam os crimes de seus subditos". ${ }^{78}$

\footnotetext{
${ }^{73}$ ANTT, Fundo Ministério do Reino, Mç. 597, doc. 03.

${ }^{74}$ Idem.

${ }^{75}$ Idem.

${ }^{76}$ BONONIENSE, Sabino. A luz moral. Lisboa: Oficina de Antonio Isidoro da Fonseca, tomo I e II, 1737.

${ }^{77}$ CARVALHO, José Maurício. A moral católica no período colonial e seu impacto na tradição luso-brasileira. Revista de Estudos Filosóficos. São João del-Rei - MG, n. 7, 2011, p. 1-13. Disponível em: https://www.ufsj. edu.br/portal2-repositorio/File/revistaestudosfilosoficos/art1_rev7.pdf. Acesso em: 1 mar. 2018.

${ }^{78}$ ANTT, Fundo Ministério do Reino, Mç. 597, doc. 03.
} 
Ainda citando os Salmatienses, o manifesto afirmava que a guerra era outro elemento que justificaria a escravidão: "os tomados em guerra justa, justamente se podem privar da vida; logo também da liberdade que he menos mal". ${ }^{79}$ Criava uma ligaçáo para legitimar a escravidão do africano sob os auspícios da Coroa e o cativeiro indígena demandado pelos moradores. Conjugando interpretaçôes dos escritos filosóficos católicos do frei Sabino Bononiense e dos Salmatienses, o manifesto buscava legitimar a escravidáo, tanto de índios quanto de africanos e ressaltar que o "resgate" era um meio válido para o cativeiro do indígena, pois salvar os prisioneiros de guerra de seus algozes é salvar-lhes a vida, o que seria mais importante do que a liberdade.

O manifesto também se debruçou sobre a história do Estado do Maranhão. Relembrando o Tratado de Tordesilhas, apontava limites nas ingerências dos reis em território americano: "suposto o Sumo Pontificie Alexandre Septimo (sic) dividio America entre os Reis de Hespanha, e Portugal, não lhes concedeo domínio absoluto, nem podia, mas sim condicionado para defenderem os Pregadores evangélicos, e os convertidos a fé catholica se necessário fosse..." ${ }^{80}$ Esses limites desaguavam na impossibilidade dos "nossos reis" de proibir que os "Principaes dos Tapuyas captivarem os seus contrários" ${ }^{81} \mathrm{O}$ ponto aqui apresentado é fundamental para a continuação da escravidão indígena: o embate entre povos nativos e a criaçáo de prisioneiros de guerra era a base da ação das Tropas de Resgate. Náo podia o rei proibir que os índios guerreassem entre si e tampouco podia proibir que os moradores fossem "resgatar" os prisioneiros.

Num jogo de destaques e omissóes, o autor do manifesto também explorou os "Annaes Históricos do Estado do Maranhão", escrito pelo governador do Estado do Maranhão (17181722), Bernardo Pereira de Berredo. ${ }^{82}$ Nesse sentido, destacou a revogação da proibição do cativeiro do gentio feita por D. João IV e publicada em 17 de outubro de 1653. Com intenção de ressaltar a posição do monarca a favor do cativeiro indígena, o autor do manifesto omitiu o fato de que a revogação foi precedida de uma legislação que tornava o índio livre. No dia 10 de novembro de 1647 , D. João IV declarou:

por quanto os Portuguezes, a que dão estas administraçôens [escravizar os índios], usão tão mal dellas, que os Índios, que estão debaixo das mesmas administraçõens, em breves dias de serviço ou morrem à pura fome, e excessivo trabalho, ou fogem pella terra adentro, onde a poucas jornadas perecem, tendo por esta causa perecido, e acabado innumeravel gentio no

\footnotetext{
79 Idem.

${ }^{80}$ Idem.

${ }^{81}$ Idem.

${ }^{82}$ BERREDO, Bernardo Pereira. Annaes Históricos do Estado do Maranhão. Maranhão: Typographia Maranhense, 1849, p. 410.
} 


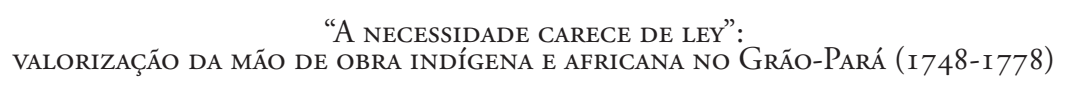

Antonio Otaviano Vieira Junior

Maranhão, Pará, e outras partes do Estado do Brasil: Pelo que Hei por bem mandar declarar por Ley (...) que os Gentios são livre... ${ }^{83}$

O manifesto conclui que não existia argumento que justificasse a escravidão dos "pretos" e não apoiasse a escravidão dos "tapuyas". A estratégia era atrelar uma escravidão à outra, evidenciando a legitimidade de ambas: para tanto, se destilava um rol de autores e de medidas administrativas adotadas pelos antecessores de D. José I. Para o autor do manifesto, tais monarcas compreendiam a importância do trabalho escravo nativo, percepção desdobrada numa série de medidas que limitava as proibiçôes da escravidão indígena.

Após o aporte histórico e filosófico, o manifesto dedicou-se a evidenciar a fragilidade da utilização de escravos africanos no Grão-Pará. O primeiro argumento tratava da pobreza dos moradores e do alto preço dos "pretos": "aquele par de prettos não remedearem a necessidade dos muitos de que carecem, para tirar lucro que avulte" ${ }^{84} \mathrm{E}$, caso os moradores comprassem africanos "fiados", poderiam não ter recursos para saldar a dívida e ter seus bens hipotecados - "ficariam em pior estado". 85

A argumentação também se baseava na desqualificação da mão de obra africana para atender às necessidades dos moradores do Grão-Pará. Os negros não estariam adaptados ao trabalho específico da região, "não servem mais que trabalharem com hua fouce, e machado". Não tinham habilidades para caçar e pescar "como fazem os tapuyas para sy e seus senhores". ${ }^{86}$ Além de não serem capazes de prover a mesa dos colonos, os africanos ainda teriam que ser alimentados.

O manifesto destacou o deslocamento interno como problema: "todo o trato desta capitania he por mar, por ser toda cortada de Rios só os tapuyas [grifo nosso] servem para remar e governar as canoas". Sem os índios, segundo o manifesto, nem brancos nem negros conseguiriam se deslocar nos matos, correndo o risco de se perderem e de morrerem na floresta - "das terras desta capitania serem todas de matos". ${ }^{87}$ Outra dificuldade era a presumida falta de habilidade que os negros teriam para fazer "paneyros, tipitis e outras cousas de que se usa no trafego de Roças”, dificultando o transporte da produção. Em poucas linhas, o manifesto reforçava a imagem de um índio nato para ser explorado, criado em canoas e ao rigor do tempo, que "resistia como ninguém" ${ }^{88}$ Por outro lado, o africano era considerado inapto para trabalhar na região, principalmente por não ter as habilidades e o conhecimento das realidades locais. De forma taxativa, o documento refu-

${ }^{83}$ BNP, "LEY, PORQUE V. MAGESTADE HA POR BEM RESTITUIR AOS INDIOS DO GRÃO PARÁ, E MARANHÃO A LIBERDADE DAS SUAS PESSOAS, E BENS, E COMMERCIO, DADA EM 6 DE JUNHO DE 1755".

${ }^{84}$ ANTT, Fundo Ministério do Reino, Mç. 597, doc. 03.

${ }^{85}$ Idem.

${ }^{86}$ Idem.

${ }^{87}$ Idem.

${ }^{88}$ Idem. 


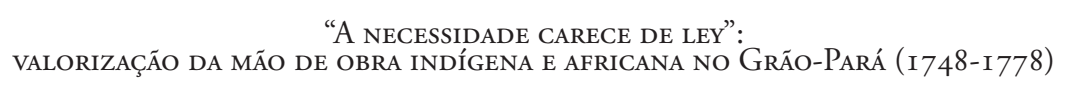

Antonio Otaviano Vieira Junior

tava a entrada de africanos e concluía: "se não pode estranhar a este povo [do Grão-Pará] a não aceytação dos pretos". ${ }^{89}$

$\mathrm{Na}$ contramão das diretrizes josefinas, o manifesto não propõe o fim da escravidão indígena. Pelo contrário, avança no sentido de reivindicar uma melhor regulação da compra desses escravos, em especial, com o fim do controle das aldeias pelos missionários. Sugere o financiamento das Tropas de Resgate pelos moradores mais abastados e, ainda, que os índios capturados por Tropas custeadas pela fazenda real pudessem ser distribuídos entre os moradores mais pobres. $\mathrm{O}$ manifesto fazia sugestôes para tornar mais acessíveis os braços escravos "tapuyas". Concomitantemente, destacava os moradores mais "pobres" como mais necessitados de subsídios para aquisição dessa mão de obra, criando uma prioridade na distribuição da escravaria indígena.

Encontramos outro documento que segue no mesmo sentido. Anônimo e datado de 11 de novembro de 1751, faz menção às esperanças no novo governo de Mendonça Furtado, à incapacidade do Estado do Maranhão pagar os "filhos da folha" pela diminuição das rendas reais e ao fato de o autor da carta ter doze anos de experiência na região - indícios de ter sido escrito por uma autoridade local. Creditava a crise ao "contagio passado [1748-1750]". ${ }^{90}$ E afirma categoricamente que as medidas reais eram insatisfatórias: "Os pretos que dizem S. Majestade há de mandar, e os Ilheos povoadores ajudão alguma cousa, mas muito pouco, e devagar, e de prezente talvez mais prejudicão". ${ }^{91}$

Mais uma vez, era destacada a debilidade das soluçóes alvitradas pelo rei, em especial, a inserção de escravos africanos. No contraponto, foram propostas soluçôes alternativas: o rei deveria mandar os missionários intensificarem descimentos para que cada aldeia nos arredores de Belém contasse com, pelo menos, 600 índios, os governadores deveriam mandar "escoltas" numa área entre 30 e 50 léguas da cidade para capturar "por estes mattos milhares de índios fugidos...", por último, deveria ser dada permissão para os moradores fazerem seus próprios descimentos nos sertôes. ${ }^{92}$ Nesse sentido, não seria a entrada de africanos que resolveria o problema de mão de obra, e sim a percepção e valorização do sertão como área de continua oferta de escravos indígenas.

O manifesto apresentou uma clara resistência à substituição do trabalho escravo indígena pelo africano, destacando o questionamento dos moradores em relação à utilidade do cativeiro negro para a economia da América setentrional portuguesa. Do outro lado do Atlântico, Lisboa tinha clareza dessa objeção, fato indicado no parágrafo sete da Instrucção real ao recém-nomeado governador Mendonça Furtado: era necessário persuadir os moradores "a que se sirvam de Escravos Negros" ${ }^{93}$ E uma das estratégias de persuasão da Coroa era

\footnotetext{
${ }^{89}$ Idem.

${ }^{90}$ ANTT, Fundo Ministério do Reino, Mç. 597, doc. 05.

${ }^{91}$ Idem.

${ }^{92}$ Idem.

${ }^{93} \mathrm{O}$ título completo era Instrucção que Vossa Mage. he servido de mandar a Francisco Xavier de Mendonça
} 
"A NECESSIDADE CARECE DE LEY":

VALORIZAÇÃo DA MÃo dE ObRA INDÍGENA E AFRICANA No GrÃo-PARÁ (I 748-I778)

Antonio Otaviano Vieira Junior

a entrada regular de cativos africanos no Grão-Pará. Nesse sentido, a Companhia Geral de Comércio do Grão-Pará e Maranhão teria um papel fundamental.

De maneira mais geral, a Companhia de Comércio estava relacionada diretamente ao esforço da administração lusitana em reduzir a importação de produtos manufaturados e matérias-primas, ${ }^{94}$ como também se articulavam a tentativa da Coroa de garantir a integridade territorial, o desenvolvimento comercial do norte da América ${ }^{95}$ e o combate a escravidão indígena. ${ }^{96}$ Esse último objetivo alinhava-se com a tentativa de transformar o indígena em colono. ${ }^{97}$

A primeira "carregação" de africanos transportados pela Companhia chegou a Belém em 1756, e logo Miguel de Bulhóes ${ }^{98}$ recomendou "que regulassem os preços dos escravos, de sorte, q este Povo acabasse de compreender a utilidade que lhe havia de resultar da Nova Companhia, e q refletissem q esta era a primeira acção dela.... ${ }^{99}$ A Galera São José trouxera na ocasiāo 91 africanos oriundos do porto de Cacheu ${ }^{100}$, ainda no mesmo ano foram enviados mais 856 escravos. ${ }^{101} \mathrm{O}$ número de cativos africanos que entrou, certamente, não atenderia a toda a demanda da capitania. Isso fica explícito ao considerarmos que, durante a epidemia, somente nas duas freguesias de Belém, faleceram 6.374 escravos indígenas das propriedades dos moradores e religiosos. ${ }^{102} \mathrm{O}$ preço de venda da escravaria era elevado e se articulava diretamente com a relação entre demanda e oferta. O levantamento feito a partir das "carregaçóes" da Companhia pode nos oferecer uma ideia do volume de escravos

Furtado Governador e Capitam General do Estado do Pará e Maranhão, ao qual chamamos resumidamente de Instrucção. BNP, Coleção Pombalina, f. 348. SOUZA, JR., José Alves. Tramas do cotidiano..."as Instruçôes constituíam-se numa verdadeira planilha de projeçóes do governo metropolitano (...) eram na verdade, indagaçōes sobre como se poderia melhor proceder para tornar a exploração da região rentável para a Coroa”, p. 93. ${ }^{94}$ BOXER, Charles. O império maritimo português 1415-1825. Lisboa: Ediçóes 70, 1969, p. 183.

${ }^{95}$ CARREIRA, Antonio. As Companhias Pombalinas de Navegação, comércio e tráfico de escravos entre a costa africana e o nordeste brasileiro. Porto: Imprensa Portuguesa, 1969. p. 35.

${ }^{96}$ SILVA, op. cit., p. 53.

${ }^{97}$ Embora a documentação aqui analisada não trate do tema, é preciso destacar que, a despeito de toda tentativa de controle do indígena, houve por parte dele uma resistência continua. Apesar do extermínio de alguns povos e a expulsão territorial de outros, os índios, efetivamente e de maneira protagonista, enfrentaram os projetos de monopólio de sua mão de obra. Cf: ROLLER, Heather Flynn. Amazonian Routes: indigenous mobility and colonial communities in Northern Brazil. Stanford: Stanford University Press, 2014. SAMPAIO, Patrícia. "Vossa Excelência mandará o que for servido...”: políticas indígenas e indigenistas na Amazônia do final do século XVIII. Revista Tempo, Rio de Janeiro, n. 12, 2007, p. 3955. FARAGE, Nádia. As muralhas dos sertóes: os povos indígenas no Rio Branco e a colonização. Rio de Janeiro: Paz \&Terra, 1991.

${ }^{98}$ Entre 1752-1756, o bispo Miguel de Bulhões foi governador interino do Estado do Grão-Pará e Maranhão, na ocasião, substituiu Mendonça Furtado que estava envolvido com as delimitaçóes de fronteiras com a Espanha. A nomeação do bispo deixava clara a sintonia entre os ditames josefinos e as ações de Miguel de Bulhôes. Cf: NEVES, Amaro. D. Frei Miguel de Bulhóes e Sousa. Aveiro: ADERAV, 2006, p. 61-80.

${ }^{99}$ BNP, Coleção Pombalina, f. 321.

${ }^{100}$ ANTT, Companhia Geral de Comercio do Pará e Maranhão (CGCPM), Livro 1.

${ }^{101} \mathrm{Idem}$.

${ }^{102}$ AU/PR, capitania do Grão-Pará, 16 de maio de 1750, cx. 31, doc. 2976. 
"A NECESSIDADE CARECE DE LEY":

VALORIZAÇÃo DA MÃo dE ObRA INDÍGENA E AFRICANA No GrÃo-PARÁ (I 748-I778)

Antonio Otaviano Vieira Junior

transportados. Seguindo exclusivamente esses dados, encontramos 14.981 africanos embarcados com destino ao porto de Belém, distribuídos em 73 "carregaçôes", entre os anos de 1758-1778. ${ }^{103}$ Desse número, subtraímos os que morreram antes do embarque, 757 mortos. Efetivamente foram embarcados 14.224 para o Grão-Pará, somamos a esse número os 947 cativos que entraram em 1756. Outra somatória, restrita aos Diários da Companhia, chega a 13.970 cativos que entraram pelo porto de Belém (1758-1778). ${ }^{104}$ Assim, podemos considerar números oscilando entre 13.970 e 15.171 transportados.

Em 1778, o governador João Pereira Caldas iniciou o levantamento sistemático dos fogos, essa contagem gerou um documento intitulado "Mapa das Famílias das Capitanias do Grão-Pará e Rio Negro”. ${ }^{105}$ A análise preliminar dessa documentação nos indica a distribuição da escravaria de origem africana, com o total de 14.199 escravos "negros"106 distribuídos pelas 63 freguesias/vilas/lugares e pelos 4.176 domicílios. As seis maiores populaçóes de cativos estavam: na Sé (2.394) e Campina (2.027), as duas freguesias formavam a cidade de Belém, Cametá (1.635), Mojú (875), São Domingos do Rio Guamá (741) e São José de Macapá (604). A soma desse plantel é de 8.276 cativos, significando que $58 \%$ dos escravos negros da capitania estavam concentrados nessas localidades. ${ }^{107}$ A maior parte da mão de obra escrava negra dessas freguesias dedicava-se diretamente à agricultura mercantil. ${ }^{108}$

${ }^{103}$ Optamos em trabalhar com uma série contínua de dados, no caso, os Livros de Carregaçóes (45-52): ANTT, CGCPM, Livros 45-52. Para Antonio Carreira, o número de escravos destinados ao Grão-Pará foi de 16.078, op. cit., p. 89. Esse número foi alcançado a partir da combinação de alguns Livros de Carregaçóes (45,46 e 47) com Livros de Balanço (77, 78 e 79).

${ }^{104}$ ANTT, CGCPM, Livros 7, 8, 9, -10, 11, 12, 13, 14 e 15. As Carregaçôes contabilizam os escravos embarcados da África para a cidade de Belém, e os Diários acusam os escravos que efetivamente entraram no porto. ${ }^{105}$ AU/PR, Capitania do Grão-Pará, 22 de junho de 1785, cx. 94, doc. 7509.

${ }^{106} \mathrm{O}$ esforço da Coroa em distanciar o indígena do africano pode ser ilustrado pelo parágrafo 10 do Diretório: onde era determinado que os diretores das Aldeias proibissem que os Índios fossem chamados ou se chamassem de "negros", "querendo talvez com a infâmia e vileza deste nome [negro], persuadir-lhes, que a natureza os tinha destinado para escravos Brancos, como regularmente se imagina a respeito dos Pretos da Costa da África”. Cf: Diretório que se deve observar nas Povoações dos Índios do Pará, e Maranhão, enquanto sua Majestade não mandar o contrário. Disponível em: http://bd.camara.gov.br/bd/handle/bdcamara/1929. Acesso em: 17 abr. 2018.

${ }^{107}$ Mesmo em fins do século XVIII e ao longo do XIX, essas regióes continuaram concentrando a maior parte do contingente de escravo da Província do Pará. Cf: BARROSO, Daniel \& MOTA, Antonia. Economia e demografia da escravidão no Maranhão e no Grão-Pará: uma análise comparativa da estrutura da posse de cativos (1785-1850). Revista História, São Paulo, n. 176, 2017, 41p. Disponível em: http://www.scielo.br/pdf/ rh/n176/2316-9141-rh-176-a07815.pdf. Acesso em: 19 mar. 2018.

${ }^{108}$ Cf: ANGELO-MENEZES, Maria de Nazaré. O sistema agrário do Vale do Tocantins colonial: agricultura para consumo e para exportação. Projeto História, Sáo Paulo, vol. 18, 1999, p. 237-259. A autora analisa o avanço da agricultura de exportação no período pombalino, na regiáo do Baixo Tocantins. Para Marcia Mello, há um indicativo de que a entrada de africanos para a lavoura náo foi suficiente, cf: MELLO, Marcia. Contribuição para uma demografia do Estado do Grão-Pará e Maranhão, 1774-1821. Anais de História de Além-Mar, Lisboa, vol. XVI, 2015, p. 227-253. MARIN, Rosa Elizabeth. 2005. Agricultura no delta do rio Amazonas: colonos produtores de alimentos em Macapá no período colonial. Novos Cadernos NAEA, vol. 8, n. 1 (jun), p. 73-114. RAVENA, Nírvia. O abastecimento no século XVIII no Grão-Pará: Macapá e as vilas circunvizinhas. In: MARIN, Rosa Acevedo (org.). A escrita da história paraense. Belém: NAEA/UFPA, 1998, p. 29-52. 
Entretanto, menos da metade da população escrava negra da capitania estava dividida entre as outras 57 localidades. Segundo o Mapa das Famílias, seis delas tinham entre 50-100 cativos, 10 tinham entre 10-49 e 22 tinham entre 00-09 escravos de origem africana. Para ampla área da capitania do Grão-Pará as açôes da Companhia não surtiram o efeito desejado pela Coroa. A região com menor número de cativos negros era o Baixo Amazonas. E mesmo após o fim do monopólio da Companhia ainda era reduzida a presença de brancos e cativos negros na capitania do Rio Negro. ${ }^{109}$

\section{Considerações finais}

Ao ter como foco a utilização da mão-de-obra indígena e africana, pontuamos uma série de tensôes entre os dois lados do Atlântico. O ponto principal de inflexão é o fim da escravidão ameríndia e a inserção de cativos africanos. Nesse sentido, se esboçavam dois projetos conflitantes.

De Lisboa através do apoio de monarcas como D. Joáo V e D. José I, do Conselho Ultramarino, de Sebastiáo José de Carvalho e Melo, do primeiro governador nomeado por D. José I para o Estado do Maranhão (Francisco Xavier de Mendonça Furtado) e do Bispo Miguel de Bulhóes vinha o fortalecimento de uma antiga demanda metropolitana de monopólio do trabalho dos indígenas. Esse projeto se apoiava na liberdade geral do índio, no fim do controle religioso das aldeias e na ampliação da oferta de escravos africanos para os moradores do norte da América lusitana - como havia sido feito para o Estado do Brasil.

No Grão-Pará outra perspectiva acerca do desenvolvimento econômico da região, mais enfaticamente na solução para demandas de mão-de-obra, aliava pontualmente moradores, vereadores, autoridades locais e o governador do Maranháo, Francisco Gurjão. Essa vertente apostava fundamentalmente na intensificação da escravidão indígena e estabelecia forte resistência à utilização do cativo africano como solução para as demandas produtivas locais.

O embate se arrastava desde o século XVI, mas ganhou novos contornos com a alta mortalidade indígena gerada pela epidemia que assolou o Grão-Pará entre 1748-1750 e com um conjunto de açóes metropolitanas, como o fim do cativeiro indígena e a entrada regular de escravos africanos. Essas ações se traduziram na publicação da Lei de Liberdade do Índio (1757), a publicação da Bula Papal (1757), a publicação do Diretório dos Índios (1757) e a criação da Companhia de Comércio do Grão-Pará e Maranhão (1755). Mas tais medidas não se efetivaram dentro da perspectiva da Coroa e encontraram sólida resistência no Grão-Pará.

\footnotetext{
${ }^{109}$ MELLO, Contribuição..., op. cit., p. 238. SAMPAIO, Patricia. Espelhos partidos. Manaus: EDUA, 2011, p. 75.
} 
Após o fim do reinado de D. José I, continuava claro que as relaçóes entre a Coroa e o Grão-Pará eram marcadas por embates e pela dificuldade de imposiçấo da vontade metropolitana, embora não se deva negligenciar a força dessa política. Como exemplo, podemos citar o Diretório dos Índios, publicado em 1757 e revogado em 1798, que foi "resultado das disputas das forças sociais reunidas na Colônia (...) e que essas forças se fizeram sentir no período em que ele vigorou". ${ }^{110}$

Embora legalmente a escravidão indígena tenha sido proibida, na prática essa mão de obra continuou sendo importante. Considerando a concentração na distribuição da escravaria africana até 1778 , podemos imaginar que as áreas com pouca ou nula presença de cativos africanos tinham a base da sua economia centrada na mão de obra compulsória indígena ${ }^{111}$ e, também, no uso que escapava às proibiçôes e determinaçôes da Coroa: uma escravidão velada do índio. Segundo Robin Anderson, até finais da década de 1780, a economia do Grão-Pará estava substancialmente atrelada ao uso da mão de obra indígena. ${ }^{112}$ Em 1764, Mendonça Furtado, então Secretário de Estado da Marinha e Ultramar, demonstrou preocupação com a não efetivação das diretivas metropolitanas de assegurar a liberdade indígena. E o fez a partir da denúncia contra as açóes do desembargador Francisco Raimundo de Morais, autoridade local que deveria estar comprometida com os ditames lisboetas: "sem atender as Leys de Sua Magestade que reputão forras todas estas Naçoens sem embargo destas Reaes determinaçoens queria este Homem [o desembargador] em muita boa consciença fazer cativo a este [da nação Canaris] mizervel índio". ${ }^{113}$

Entre leis reais revogadas, Bulas papais, inverdades de um governador e resistência à mão de obra africana assistimos à tentativa de imposição de leis que tentavam garantir a liberdade indígena e o fluxo regular de escravos africanos para o Grão-Pará. Também percebemos indícios da permanência da utilizaçáo do trabalho do índio, que poderia significar a exploração compulsória e/ou o cativeiro ilegal. Assim, a possibilidade da liberdade indígena e do maior uso do trabalho do escravo africano orbitava entre as tensóes de interesses da Coroa, demandas dos moradores, empreitadas religiosas e as estratégias de resistência do indígena. Resumidamente na expressão utilizada pelos moradores: "a necessidade carece de ley"114.

\footnotetext{
${ }^{110}$ COELHO, Mauro Cezar. Do sertão para o mar, op. cit., p. 93.

${ }^{111}$ Trabalho Compulsório é definido como aquele trabalho em que o empregado não pode se retirar quando quer sem correr o risco de punição, mesmo que receba remuneração em troca do serviço prestado. Cf: BRITO, Célia Maria Chaves. Índios das "corporaçôes": trabalho compulsório no Grão-Pará no século XVIII. In: MARIN, Rosa Acevedo (org). A escrita da História paraense. Belém: NAEA/UFPA, 1998, p. 115-137.

${ }^{12}$ ANDERSON, Robin. Following Curupira: Colonization and migration in Pará, 1758 to 1930 as a study in settlement of the humid Tropics. Tese (Doutorado em História), Universidade da Califórnia em Davis, 1976.

${ }^{113}$ AU/PR, Capitania do Grão-Pará, janeiro de 1764, cx. 55, doc. 5024.

${ }^{114}$ ANTT, Fundo Ministério do Reino, Mç. 598, doc. 55.
} 


\section{Fontes}

ARQUIVO NACIONAL DE PORTUGAL/TORRE DO TOMBO (ANTT). Companhia Geral de Comercio do Pará e Maranhão (CGCPM), livros 1, 7, 8, 9, 10, 11, 12, 13, 14 e 15. ARQUIVO NACIONAL DE PORTUGAL/TORRE DO TOMBO (ANTT). Fundo Ministério do Reino, Mç. 597, doc. 02.

ARQUIVO NACIONAL DE PORTUGAL/TORRE DO TOMBO (ANTT). Fundo Ministério do Reino, Mç. 597, doc. 03.

ARQUIVO NACIONAL DE PORTUGAL/TORRE DO TOMBO (ANTT). Fundo Ministério do Reino, Mç. 597, doc. 05.

ARQUIVO NACIONAL DE PORTUGAL/TORRE DO TOMBO (ANTT). Fundo Ministério do Reino, Mç. 598, doc. 55.

ARQUIVO NACIONAL DE PORTUGAL/TORRE DO TOMBO (ANTT). Livros de Carregações (45-52): CGCPM, Livros 45-52.

ARQUIVO ULTRAMARINO - PROJETO RESGATE (AU/PR). Capitania do GrãoPará, jan. 1764, cx. 55, doc. 5024.

ARQUIVO ULTRAMARINO - PROJETO RESGATE (AU/PR). Capitania do GrãoPará, 22 jun. 1785, cx. 94, doc. 7509.

ARQUIVO ULTRAMARINO - PROJETO RESGATE (AU/PR). Capitania do Maranhão, 15 mai. 1750 , cx. 31, doc. 3213.

ARQUIVO ULTRAMARINO - PROJETO RESGATE (AU/PR). Capitania Pará, 28 out. 1747, cx. 29, doc. 2803.

ARQUIVO ULTRAMARINO - PROJETO RESGATE (AU/PR). Capitania do Pará, 30 mai. 1749, cx. 31, doc. 2917.

ARQUIVO ULTRAMARINO - PROJETO RESGATE (AU/PR). Capitania Pará, 26 abr. 1749, cx. 31, doc. 2910.

ARQUIVO ULTRAMARINO - PROJETO RESGATE (AU/PR). Capitania do Pará, 16 mai. 1750, cx. 31, doc. 2976.

ARQUIVO ULTRAMARINO - PROJETO RESGATE (AU/PR). Capitania do Pará, 12 nov. 1755, cx. 39, doc. 3676.

BIBLIOTECA NACIONAL DE PORTUGAL (BNP). "Ley, porque V. Magestade ha por bem restituir aos indios do Grão Pará, e Maranhão a liberdade das suas pessoas, e bens, e commercio, dada em 6 de junho de 1755".

BIBLIOTECA NACIONAL DE PORTUGAL (BNP). Coleção Pombalina, f. 321.

BIBLIOTECA NACIONAL DE PORTUGAL (BNP). Coleção Pombalina, f. 348. 
"A NECESSIDADE CARECE DE LEY":

VALORIZAÇÃo DA MÃO DE OBRA INDÍGENA E AFRICANA NO GRÃO-PARÁ (I 748-I778)

Antonio Otaviano Vieira Junior

\section{Referências}

ALMEIDA, Maria. A falácia do povoamento: ocupação portuguesa na Amazônia setecentista. In: COELHO, Mauro Cesar. Meandros da História. Belém: Unamaz, 2005. p. 21-33.

ANDERSON, Robin. Following Curupira: Colonization and migration in Pará, 1758 to 1930 as a study in settlement of the humid Tropics. Tese (Doutorado em História), Universidade da Califórnia em Davis, 1976.

ANGELO-MENEZES, Maria de Nazaré. O sistema agrário do Vale do Tocantins Colonial: agricultura para consumo e para exportação. Projeto História, São Paulo, v. 18, 1999, p. 237-259.

BARROSO, Daniel \& MOTA, Antonia. Economia e demografia da escravidão no Maranhão e no Grão-Pará: uma análise comparativa da estrutura da posse de cativos (1785-1850). Revista História, São Paulo, n. 176, 2017, 41p. Disponível em: http://www.scielo.br/pdf/rh/ n176/2316-9141-rh-176-a07815.pdf. Acesso em: 19 mar. 2018.

BEZERRA NETO, José Maia. Escravidão negra no Grão-Pará: séc. XVII-XIX. Belém: Paka-Tatu, 2001.

BICALHO, Maria Fernanda \& COSTA, André. O Conselho Ultramarino e a emergência do Secretário de Estado na comunicação política entre Reino e Conquistas. In: FRAGOSO, João e MONTEIRO, Nuno (orgs.). Um reino e suas repúblicas no Atlântico. Rio de Janeiro: Civilização Brasileira, p. 137-158.

BOXER, Charles. A Idade de Ouro do Brasil. São Paulo: Companhia Ed. Nacional,1963.

BOXER, Charles. O império maritimo português 1415-1825. Lisboa: Ediçóes 70, 1969.

BRITO, Célia Maria Chaves. Índios das “corporações”: trabalho compulsório no Grão-Pará no século XVIII. In: MARIN, Rosa Acevedo (org). A escrita da História paraense. Belém: NAEA/UFPA, 1998, p. 115-137.

Bularium Benedicti XIV. Tomus Primi. Roma: Typographi Celsiss, vol. I, 1826.

CARREIRA, Antonio. As Companhias Pombalinas de Navegação, comércio e tráfico de escravos entre a costa africana e o nordeste brasileiro. Porto, Imprensa Portuguesa, 1969.

CARVALHO, José Maurício. A moral católica no período colonial e seu impacto na tradição luso-brasileira. Revista de Estudos Filosóficos. São João del-Rei - MG, n. 7, 2011, p. 1-13. Disponível em: https:/www.ufsj.edu.br/portal2-repositorio/File/revistaestudosfilosoficos/ art1_rev7.pdf. Acesso em: 1 mar. 2018.

CARVALHO Jr., Roberto. Dominar homens ferozes: missionários carmelitas no Estado do Maranhão e Grão-Pará (1686-1757). Dissertação (Mestrado em História) - Programa de Pós-Graduação em História Social, Universidade Federal da Bahia, Salvador, 2015.

CHAMBOULEYRON, Rafael. Suspiros por um escravo de Angola: discurso sobre a mão 


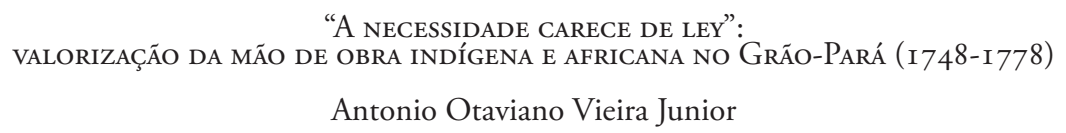

de obra africana na Amazônia Seiscentista. Revista Humanitas, Belém, v. 20, n. 1/2, 2004, p. 99-111.

COELHO, Mauro Cezar. Do sertão para o mar: um estudo sobre a experiência da América, a partir da Colônia; o caso do Diretório dos Índios (1750-1798). Tese de Doutorado, Universidade de São Paulo, 2005.

COSTA, João Paulo Oliveira (org.). História da expansão e do Império português. Lisboa: Bertrand, 2014.

DIEGUES JR., Miguel. As Companhias Privilegiadas no comércio colonial. Disponível em: http://www.revistas.usp.br/revhistoria/article/viewFile/34853/37591, p. 321. Acesso em 6 fev. 2018.

DOMINGUES, Ângela. 2000. Quando os indios eram vassalos: colonizaçâo e relaçôes de poder no Norte do Brasil, na segunda metade do século XVIII. Lisboa: Comissão Nacional de Comemoraçóes dos Descobrimentos Portugueses, 2000.

FARAGE, Nádia. As muralhas dos sertóes: os povos indígenas no Rio Branco e a colonização. Rio de Janeiro: Paz \&Terra, 1991.

FEIO, David Salomão. O nó da rede de 'apaniguados': oficiais das câmaras e poder político no Estado do Maranhão (primeira metade do século XVIII). Dissertação (Mestrado em História Social), Programa em História Social da Amazônia, Universidade Federal do Pará, Belém, 2013.

FONSECA, João Abel. D. Frei Miguel de Bulhôes, bispo do Pará e governador do Estado do Grão-Pará e Maranhão. 1752-1756. In: Congresso Internacional de História Missionação Portuguesa e Encontro de Culturas, 1993, Braga. Actas... Braga: Fundação Evangelização e Culturas, vol. II, 1993.

FRAGOSO, João. Uma leitura do Brasil Colonial: bases da materialidade e da governabilidade do Império. Revista Penélope, Oeiras, n. 23, 2000, p. 67-88.

FRAGOSO, João et al. O Antigo Regime nos trópicos. Rio de Janeiro: Civilização Brasileira, 2001.

FRAGOSO, João. Poderes e Mercês nas conquistas americanas de Portugal (século XVII e XVIII): apontamentos sobre as relaçôes centro e periferia na monarquia pluricontinental lusa. In: FRAGOSO, João e MONTEIRO, Nuno (orgs.). Um reino e suas repúblicas no Atlântico. Rio de Janeiro: Civilização Brasileira, 2017, p. 49-99.

GOMES, Robeilton. Nos Limites do Poder: o processo de construção da lei de liberdade dos índios do Grão-Pará (1751-1757). Canoa do Tempo, Manaus, v. 9 - n. 1, dez 2017, p. 114-137.

GUZMÀN, Décio. 2012. Guerras na Amazônia do século XVIII: resistência indígena à colonização. Belém: Estudos Amazônicos, 2012. 


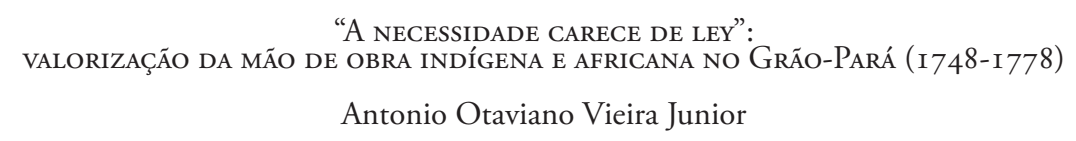

HESPANHA, Antonio Manuel. A constituição do Império português: revisão de alguns enviesamentos correntes. In: FRAGOSO, João et al. O Antigo Regime nos trópicos. Rio de Janeiro: Civilização Brasileira, 2001. p. 164-188.

MELLO, Marcia. Contribuição para uma Demografia do Estado do Grão-Pará e Maranhão, 1774-1821. Anais de História de Além-Mar, Lisboa, vol. XVI, 2015, p. 227-253.

MONTEIRO, Nuno. D. José. Lisboa: Círculo dos Leitores, 2006.

MUNIZ, Durval. História: a arte de inventar o passado. Bauru-São Paulo: Edusc, 2007.

NEVES, Amaro. D. Frei Miguel de Bulhöes e Sousa. Aveiro: ADERAV, 2006.

PAIVA, José Pedro. Os bispos do Brasil e a formação da sociedade colonial (1551-1706). Textos de História - Pós-Graduação em História da UNB. Brasília-DF, v. 14, n. 1/2, p. 19, 2006.

RAVENA, Nírvia. O abastecimento no século XVIII no Grão-Pará: Macapá e as vilas circunvizinhas. In: MARIN, Rosa Acevedo (org). A escrita da história paraense. Belém: NAEA/UFPA, 1998, p. 29-52.

ROLLER, Heather Flynn. Amazonian Routes: indigenous mobility and colonial communities in Northern Brazil. Stanford: Stanford University Press, 2014.

SAMPAIO, Patrícia. "Vossa Excelência mandará o que for servido...”: políticas indígenas e indigenistas na Amazônia do final do século XVIII. Revista Tempo, Rio de Janeiro, n. 12, 2007, p. 39-55.

SAMPAIO, Patrícia. Espelhos partidos. Manaus: EDUA, 2011, p. 75.

SILVA, Maria Beatriz Nizza da. D. João V. Lisboa: Círculo dos Leitores, 2006.

SOUZA JR., José Alves. Jesuítas, colonos e índios: a disputa pelo controle e exploração do trabalho indígena. In: ALONSO, José Luis \& CHAMBOULEYRON, Rafael (org.). T(r)ópicos de História: gente, espaço e tempo na Amazônia (séculos XVII-XXI). Belém: Editora Açaí, 2010, p. 47-64.

ALONSO, José Luis \& CHAMBOULEYRON, Rafael (org.). Índios: mãos e pés dos senhores da Amazônia colonial. Fronteras de la Historia, Bogotá, vol. 16-2, p. 365-391, 2011.

ALONSO, José Luis \& CHAMBOULEYRON, Rafael (org.). Tramas do cotidiano. Belém: EDUFPA, 2012.

SANTOS, Fabiano Vilaça dos. Da Paraíba ao Estado do Maranhão: trajetórias de governo na América Portuguesa (séculos XVII e XVIII), Revista de História, São Paulo, n. 161, $2^{\circ}$ semestre de 2009, p. 59-83.

VAINFAS, Ronaldo. Dicionário do Brasil Colonial (1500-1808). Rio de Janeiro: Objetiva, 2000.

VIEIRA JR., Antonio Otaviano e MARTINS, Roberta. Epidemia de Sarampo e Trabalho Escravo no Gráo-Pará (1748-1778). Revista Brasileira de Estudos de População, Campinas, 2015 , v. 32, n. 2, p. 293-311. 